\title{
AN ECONOMETRIC ANALYSIS OF THE RELATIONSHIP BETWEEN THE NUMBER OF TOURISTS COMING TO TURKEY AND THE TRANSPORTATION EXPENDITURE
}

\author{
DOI: 10.17261/Pressacademia.2020.1287 \\ JMML- V.7-ISS.3-2020(5)-p.154-159
}

\section{Beyhan Incekara}

Istanbul Kent University, Faculty of Humanities and Social Sciences, Department of International Trade and Logistics, Istanbul, Turkey. beyhan.incekara@kent.edu.tr, ORCID: 0000-0002-4937-0868

Date Received: May 22, 2020

Date Accepted: August 28, 2020

To cite this document

Incekara, B., (2020). An econometric analysis of the relationship between the number of tourists coming to Turkey and the transportation expenditure. Journal of Management, Marketing and Logistics (JMML), V.7(3), p.154-159.

Permanent link to this document: http://doi.org/10.17261/Pressacademia.2020.1287

Copyright: Published by PressAcademia and limited licensed re-use rights only.

\begin{abstract}
Objective - The study aims to explain the relationship between the number of tourists, which is an important factor in the tourism sector, and the transportation expenditures, which have an important place in the passenger transport and the development of tourism within the public expenditures.

Methodology - The relationship between transportation expenditures (TE) and the number of incoming tourists to Turkey (TOU) has been studied empirically. The number of incoming tourists and the relationship of transportation expenditures made by the public were analyzed with the Toda Yamamoto causality test.

Findings- The number of incoming tourists and transportation expenditures were analyzed with Toda Yamamoto causality test and a unilateral causality relationship was found between the number of tourists and transportation expenditures. Accordingly, there is a unilateral causality relationship from the transportation expenditure to the number of tourists.

Conclusion - After reviewing previous studies it was concluded that this study contributes to the literature and science as there isn't any other study that examine the public transportation expenditures and the number of incoming tourists with this method. There is a unilateral causality relationship from the transportation expenditure to the number of tourists. In other words, as the number of tourists increases, transportation expenditures increase to meet the need. In addition, the analysis showed that tourists do not see the transportation system in the country of destination as an important criterion.
\end{abstract}

Keywords: Tourism, number of tourists, transportation expenditures, Toda Yamamoto, VAR analysis.

JEL Codes: E00, F00, Z30

\section{INTRODUCTION}

Transportation is the first pillar of the tourism sector. Because tourism movements cannot be realized without the means and vehicles of transportation. Therefore, the most important factor that make tourism necessary and valuable, is transportation (Korosteleva, 2013). Transportation also has important functions for tourists. First of all, four important factors such as security, comfort, cost and speed are the basis of transportation. When we separate transport activity as freight transport and passenger transport, passenger transport comes to the fore in terms of tourism sector. The importance of the transport factor in terms of tourism is grouped as follows (Ataberk, 2009): Transport allows visiting the touristic areas of a country, transport is an important source of foreign currency inflow as it supports tourism, the means of transport not only provide people with mobility, but also support the economic and touristic development of their country.

In world economies, tourists have a variety of expectations from the transport sector when they arrive in the country of destination and while they travel during their time of stay. Countries diversify their transport investments in line with these needs and expectations. The first of these factors is speed, which is very important in terms of airway transportation. For this reason, activities to build or expand airports in regions with potential for tourism are carried out. The other factor is comfort, which tourists want to travel comfortably and conveniently in all modes of transport. For this reason, all transportation companies 
increase comfort with the latest technology and innovations. The next factor is security. Passengers want to feel safe both in terms of personal safety and for their property. The price of the transportation service is also especially important in terms of the cost and the price that the tourist will cover. When we look at the tourism sector in Turkey, the number of visitors who came to the country for touristic purposes in the nineties, when the development of tourism began, was 5.3 million, while in the 2000 s, this figure exceeded 10 million, by the 2010s, Turkey has now held an important place among the world countries and reached 30 million figures, in recent years, Turkey ranked as the 6th most preferred country of tourism (TÜROFED, 2019).

Therefore, when transportation investments in 2020 are analyzed, it is seen that expenditures are as follows in order to meet the increasing tourism needs; for railway transport 10.7 billion TL, for road transport 6.7 billion TL, for urban transportation 5.8 billion $\mathrm{TL}$, for airway transport 1.2 billion TL, for highways 343.9 billion TL, and for maritime transport 390.7 billion TL. Maritime transport manifests itself in freight transport. In terms of tourism, passenger transportation is mainly realized by airway and road transport. Public expenditures are examined under three headlines in terms of their form. These are current expenditures, transfer expenditures and investment expenditures. Current expenditures are expenses related to public consumption. Even though the expenditure on education, healthcare services and social security services are found under this expenditure item, expenditure regarding the development of agricultural services which have economical infrastructure are also counted among the current expenditures. In addition to all of these, personnel expenses are also among the expenditure items listed under the current expenditures. Investment expenditures are expressed as public expenditures aimed at increasing the efficiency of the economy both in the current period and in future periods and maintaining economic sustainability. What these expenditures have in common is that they have goals such as capital accumulation, job creation and increasing production capacity. In this sense, the expenditure items accepted within the investment expenditures can be counted as follows:

- $\quad$ Expenses of construction, facilities and major repairs

- $\quad$ Study and project expenses

- $\quad$ Purchase and repair of machinery, equipment and vehicles

When these spending items are taken into account, it will be seen that a significant proportion of transportation expenditures are included in the investment expenditures section. Indeed, transportation investment, which are quite large in volume, will be placed under the item of investment expenditures which are considered transport expenditure, since they require a high expenditure of machinery, equipment, vehicle and personnel and a high expenditure in terms of survey cost and repair transportation expenses. The most important item within the scope of transportation expenditures is transportation investment expenditures. However, there are also various additional expenditures that will be added to these investments. Since transportation expenditures are large-scale investments, there are many additional expenses, especially pre-feasibility studies.

Transportation expenditures are also seen as consumption expenditures made by households. For example, post-2020 consumption expenditures of transport group in Turkey, is at an average of $20 \%$, but in 2014 , they rose to an average of $37 \%$. This is due to the increase in public transport investments and expenditure. In this study, transportation expenditures made by the public are examined. Transfer expenditures are defined as expenditures that do not have the quality of demand in the relevant current period and that only enable the exchange of ownership of the elements of wealth between individuals and institutions in a sense. These expenditures are not made in return for goods or services, nor are these expenditures made without provision. Examples of such expenditures are debt interest payments, government bond payments, social allowances and tax returns. The transport sector and the tourism sector have been feeding each other for a long time. In recent years, Turkey has reached 58 airports, also the share of maritime passenger transportation has been increased with the cruise tourism. Along with high-speed trains and new technology, efforts are also being made to accelerate railway transport. Activities are being carried out to establish a tourism network with integrated transport and multi modal structures along with the road transport. In this study, the relationship between tourism and transportation is explained and the tourism sector and tourist numbers in Turkey are provided. In addition, transportation expenditures in Turkey are analyzed. Afterwards, the relationship between transportation expenditures (TE) and the number of tourists coming to Turkey (TOU) is analyzed empirically and it is explained with a review of literature. Finally, the number of incoming tourists and transportation expenditures made by the public are investigated with the Toda Yamamoto causality test. The findings are interpreted.

\section{LITERATURE REVIEW}

Various studies have been carried out in many countries. In the research conducted by Korosteleva (2013), the performance analysis of the transportation system in tourism logistics was conducted through interviews and surveys, and the problems experienced by tourists during transportation were identified and performance criteria were adopted for the better operation of the system. The analysis of supply and logistics in tourism was performed and the performance analysis of the transport mode 
was conducted according to mode of transport used. While performance analysis was carried out, interview and survey methods were employed and it was determined what kinds of problems tourists experience in countries where they travel. Various policy proposals have been put forward to solve these problems. In a study conducted by Incekara, Dördüncü \& Özer (2015), the transportation system is examined in terms of maritime transport, the transport system within tourism. It is stated that the share of maritime transport is increasing, but it is emphasized that in order to increase this ratio, it should be supported with integration of transport systems such as port - road - railway - airway. It was stated that the share of maritime transport in freight transport is higher, while it has a smaller share in passenger transport. Various practices and policies have been proposed to increase the share of maritime transport in passenger transport. In particular, multi-modal transport has been brought to the fore. The integration of transport types was analyzed. In a study conducted by Hepsağ (2016), seasonal unit root testing with monthly data was employed for 20 major tourism markets in Turkey. According to the results of the study, in addition to the convergence of tourism markets, it was found that in the months of January, March, April, May, July, September and October there were convergences in the long term. The countries with the largest share of tourism market and in which months of the year the countries converge were examined with seasonal data, which revealed what needs to be done in order to spread tourism to all months of the year. It was also found that there were similarities while examining 20 major tourism countries.

The study conducted by Özcan and Erdoğan (2017), which used LM (RALS-LM) unit root test with monthly data for 14 major tourism markets in Turkey, concluded that convergence is valid for 10 tourism markets. In this study, 14 countries that hold an important place in the tourism market were studied with monthly data based on all months. The similarities of countries in terms of tourism were investigated. The study found that 10 countries out of 14 converged in the tourism market as a result of unit root tests. In the study conducted by Dinçer and Taşkıran (2016), the development of domestic tourism with airway transportation in Turkey and the inauguration of new domestic flights and points of Turkish Airlines, which is a national pioneer in this regard, and tourism mobility were evaluated with semi-structured interviews. Airway transportation among transportation modes was examined and the weight of airway transportation was shown to be effective in the development of domestic tourism in Turkey. How the expansion of Turkish Airlines, which has the largest share in passenger transportation and which is a pioneer, affects tourism was determined by the interview method. In the study conducted by Özdemir (1995), the importance of TCDD (State Railways of the Republic of Turkey) was examined in terms of tourism transportation. In tourism, especially in passenger transport, the leading mode of transport is airway and road transport. However, investments in railway transport have been increasing in recent years. This in turn improves tourism. The study examined the relationship of railways and tourism through analytical analysis. In the study conducted by Aşan (2006), various characteristics of foreign tourists, that visit Turkey, were examined with a Graphical Categorical Data Analysis. It was recorded that the months of July-August is a period of intense tourist inflows, and between the months of January and June more tourist than what was expected, visited Turkey. It was stated that tourists come to Turkey primarily for sightseeing and entertainment purposes. Many categories such as tourists coming to Turkey, region , country ... etc. were examined and it was found that due to the seasonal effects during summer months the volume of tourism was bigger. Graphical and categorical data analysis were used as method.

In a study on enterprises of tourism transportation in Safranbolu, conducted by Cinkara (2017), it was stated that electric vehicles can be combined with solar systems and used in transportation to reduce the cost of transportation vehicles that traveling tourists demand from businesses. In the example of Safranbolu tourism region, the applications to reduce costs in the practices to meet the expectations of the tourist coming to region from the tourism enterprises were investigated. In the study conducted by Doğan and Dikmen (2018), the types of transport within the transport sector were examined on the basis of data in passenger transport and freight transport in Turkey and transport modes were compared. In the research carried out by analytical analysis method, swot analysis of transport systems such as road transport, airway transport, maritime transport and railway transport were conducted in terms of both passenger transport and freight transport. In the study, it is stated that while maritime transport and road transport are ahead in freight transport, airway transport and road transport are at the forefront in passenger transport. Kockelman et al. (2013) touched upon the cost-benefit assessment of improving networks in terms of economic impact of transport policies and practices. In addition, they examined the economic effects of congestion in pricing, by-pass (relief roots) systems and the transportation in the form of collecting from the road which is described as "right of way". Regarding the economic consequences of the expenditure done for the improvement of transportation, Lakshman and Lata (2005) express more freight and preferred popularity in economic effects by separating the economic impact in terms of short-and long-term, defining the short-term effects of expenditure with the return to the economy as well as shortening the duration of the journeys. However, in terms of long-term benefits, it is pointed out that disruptions are minimized depending on the routine course of maintenance activities and the consequence of economic benefits that depend on the outcome of preventing the occurrence of problems rather than troubleshooting. Immer and Stada (2004) suggest that these effects should be evaluated in a very broad perspective, not only in the context of contributions to the economy, but also in relation to the economic impact of transport expenditure, together 
with direct and indirect investments in terms of transport fundamentals. Air pollution, noise pollution, accident costs, direct expenditures, investments and transportation revenues are other elements that make up this broad perspective.

\section{DATA AND METHODOLOGY}

The relationship between transportation expenditures (TE) and the number of incoming tourists to Turkey (TOU) has been studied empirically. Depending on the availability of the data, study used annual data that covers the period between 1985-2019. The data were obtained from the Ministry of Transport, Bumko, TÜRSAB tourism statistics. Finally, in empirical analysis, the logarithm of variables was taken. In this study, causality analysis proposed by Toda and Yamamoto (1995) was used to examine the relationship between transportation expenditure and number of tourists. The advantage of this method developed by Toda and Yamamoto (1995) is that it enables accessing to causality findings through the VAR model independently of the inter-series cointegrated relationship. In the Toda-Yamamoto causality test, time series form a VAR model using level values of numerous levels - it does not matter which level- of order stationarity. In this test, which consists of two stages, firstly the optimal delay length is determined and the maximum degree of integration (dmax) is determined for the series that are subject to application. Determining the appropriate delay length for the VAR model is carried out using criteria such as Akaike and Hannan-Quinn. Thus, the augmented VAR model which includes the delay length of $\mathrm{K}+\mathrm{dmax}$ is estimated with the detection of $\mathrm{k}$, the optimal delay length with dmax, the maximum degree of integration. In the second phase, Wald tests are applied to the k delayed VAR coefficient Matrix, hence Granger causality-related inferences can be made. Firstly, Augmented Dickey-Fuller (ADF) unit root test was employed to determine the order stationarity of variables. The results of ADF unit root tests applied to the levels and first differences of variables are presented in the table.

Another advantage of this method proposed by Toda Yamamoto is that it allows causality inferences based on the VAR model regardless of whether the series are cointegrated or not. In addition, the fact that this approach does not require the use of some pre-tests, which are necessary for unit root tests, also makes the Toda Yamamato test more preferable. On the procedural side of the Toda Yamamoto test, which can be applied to the level values of the series, an improved Wald test (MWALD), which applies restriction tests to the parameters of the K-delayed VAR model, is used. First step of this two-step procedure is to determine the optimal length of $k$ delay and the maximum degree of integration (dmax) for the series in the system. Criteria such as Akaike and Hannan-Quinn can be used to determine the appropriate delay length for the VAR model. With the determination of optimal delay length $(k)$ and maximum degree of integration (dmax), an improved VAR model containing a total delay length of $k+d m a x$ can be estimated. The second step of the procedure is performed by applying Wald tests to the VAR coefficient matrix with a delay length of $k$, which has been obtained to make inferences based on Granger causality.

Table 1: ADF Unit Root Test Results of the Levels and Differences of Variables

\begin{tabular}{ccc}
\hline & Augmented Dickey-Fuller (ADF) unit Root Test & t-statistic \\
\hline Variables & Delay Length & -1.95957 \\
\hline TE & 0 & -2.65854 \\
TOUR & 0 & $-5.72008^{*}$ \\
$\Delta$ TE & 0 & $-4.67099^{*}$ \\
\hline TOUR & 0 & 0 \\
\hline \hline
\end{tabular}

Notes: The symbol of * shows that the existence of the unit root with the zero hypothesis at the level of $5 \%$ significance is rejected. Delay lengths were determined using the Akaike Information Criterion (AIC). The symbol of " $\Delta$ " shows that the first level of difference of series is taken.

Firstly, expanded Dickey-Fuller (ADF) and Phillips-Perron (PP) unit root tests were employed to determine the stasis order of variables during the investigation of the relationship between variables with causality analysis developed by Toda and Yamamoto (1995). According to the results of the ADF unit root test, shown in Table 1, the transportation expenditure and number of tourist's variables are first-order stationary variables. The models established for the Toda-Yamamoto causality test adapted to the study are as follows:

$$
\begin{gathered}
U L H_{t}=\alpha_{1}+\sum_{i=1}^{k+d \max } \beta_{1 i} T_{U R}+\sum_{t=1}^{k+d \max } \theta_{1 i} U L H_{t-i}+\varepsilon_{1 t} \\
T U R=\alpha_{2}+\sum_{i=1}^{k+d \max } \beta_{2 i} U L H_{t-i}+\sum_{i=1}^{k+d \max } \theta_{2 i} T U R_{t-i}+\varepsilon_{2 t}
\end{gathered}
$$


Accordingly, $\mathrm{k}$ was designated as " 1 " according to the VAR model, dmax as " 1 ", and the augmented VAR(2) model was estimated by the seemingly unrelated regression method. The causality analysis results obtained by this model are shown in Table 2 .

Table 2: Toda-Yamamoto Causation Analysis Results

\begin{tabular}{ccc}
\hline Zero Hypothesis & Delay Length & MWALD Statistic \\
\hline TOU $R+\boldsymbol{T E}$ & 2 & $5.08269^{*}$ \\
$\boldsymbol{T E}+\boldsymbol{T O U R}$ & 2 & 1.49435 \\
\hline \hline
\end{tabular}

The symbol of * shows the rejection of the zero hypothesis at $5 \%$ significance level.

According to the results in Table 2, a unilateral causality relationship was found between the number of tourists and the transportation expenditure. Accordingly, there is a unilateral causality relationship from the transportation expenditure to the number of tourists. While the number of tourists affects the transportation expenditure, transportation expenditure does not affect the number of tourists. The study examined the tourism sector, which is one of the strategic sectors of Turkey, and examined the relationship between the number of incoming tourists and transportation expenditures, which holds a very important place in public expenditures. Transportation expenditures mainly invested on road transport, airway transport, maritime transport and railway transport. Considering that the first pillar of tourism is transportation, the incoming tourist reach the country of destination by using transportation modes. The number of incoming tourists and transportation expenditures were analyzed with Toda Yamamoto causality test and a unilateral causality relationship was found between the number of tourists and transportation expenditures. Accordingly, there is a unilateral causality relationship from the transportation expenditure to the number of tourists. While the number of tourists affects transportation spending, transportation expenditure does not affect the number of tourists. In other words, as the number of incoming tourists increases, investments in transportation systems increase as well, since it is alternative in terms of investment and it meets the need for tourism. Because the number of tourists in Turkey has increased considerably in recent years and has positively affected the balance of payments as an important source of foreign exchange returns. There have been investments in transportation to meet this demand and needs. Internal and external transportation investments were made to make travelling comfortable, convenient and fast with the optimum cost. Again, as stated in the study, transportation, accommodation facilities and expenditures do not affect the number of tourists. When we look at the travel demands of tourists, factors such as seasonal effects, cultural trips and price of travel come first. The transportation system is not seen as the first priority for the tourist who will demand tourism. Because of globalization, development of technology and increased mobility, access to even the most remote places is possible. Therefore, while the distance and location of the point of destination were important criteria before, it is no longer seen as such.

\section{CONCLUSION}

Tourism is one of the sectors that is positively affected by globalization. Because the increase in knowledge, technology and mobility has led people to travel more. Today, tourism contributes $9 \%$ of global national income and provides significant employment. The study found a unilateral causality relationship between the number of tourists and the transportation expenditure. Accordingly, there is a unilateral causality relationship from the transportation expenditure to the number of tourists. While the number of tourists affects transportation expenditure, transportation spending does not affect the number of tourists. As tourists come to the country, new transportation expenditures are realized in order to provide both international and domestic circulation as an alternative to the airways. The acceleration of passenger transport will also accelerate tourism activities. In addition, the analysis showed that tourists do not see the transportation system in the country of destination as an important criterion. The study examined the number of incoming tourists, first situation tourist face when they enter the country of destination, the transport system that they use during their stay, and their expenditures, to improve the tourism sector. It is observed that countries with developed transportation systems in passenger transport accelerate the tourism activities. In other words, as the number of tourists increases, transportation expenditures increase as indicated with numbers in the introduction section. In addition, considering the strategic tourism policies implemented and the fact that Turkey is a country of tourism, as the number of tourists increases the number of airports, activities of the sea passenger transportation, and road expenditures in Turkey increase. In contrast, transportation systems remained among the less important criteria for tourists. While the distance and lack of transportation were the important factors affecting the demand of tourists, now thanks to the globalization, development of technology and the increase of mobility has rendered these criteria trivial. Accommodation preferences, seasonal tourism, entertainment opportunities and prices are more important. Turkey has a strong tourism potential. There are numerous possibilities such as summer tourism, health tourism and cultural tourism. However, transportation systems have several problems. For example, low speed and energy costs in road transport, low speed of railway lines, lack of marinas in maritime transport, lack of ports, tourist problems and fuel costs in airway transport and sensitivity to international policies. The resolution 
of such issues will increase the existing potential. In recent years, road transport was made easier with integrated transport by connecting the highways. The development of the cruise tourism facilitated the maritime transport. Opening of new airports directed tourists to airway transport.

\section{REFERENCES}

Aşan Z. (2006). Türkiye'ye Gelen Yabancı Turistlerin Çeşitli Özelliklerinin Grafiksel Kategorik Veri Analizi ile İncelenmesi, Anatolia: Turizm Araştırmaları Dergisi, Cilt 17, Sayı 2, Güz: 153-160, 2006, ISSN: 1300-4220 (1990-2006).

Ataberk, E. (2009). Organizasyonlarında Hizmet Kalitesi ile Müşteri Tatmini arasındaki İlişkileri Belirleyen Faktörler: İzmir İli Örneği, (Yayınlanmamış Yüksek Lisans Tezi), Dokuz Eylül üniversitesi, Sosyal bilimler enstitüsü, Turizm işletmeciliği anabilim dalı, Turizm işletmeciği programı, İzmir.

Cinkara A.(2017). İnovatif bir düşünce olarak solar sistemlerin yerel işletmelerde kullanımı: Safranbolu turizm ulaştırma işletmeleri üzerine bir araştırma, Karabük Üniversitesi / Sosyal Bilimler Enstitüsü / İşletme Anabilim Dalı, Yüksek Lisans Tezi

Dinçer F., Taşkiran Ö., (2016). Türkiye'de Havayolu Ulaşiminin Gelişimi ve İç Turizm Hareketlerine Etkisi Açisindan Değerlendirilmesi:Thy Örneği, 17. Ulusal Turizm Kongresi Bildiri Metni, 20-23 Ekim 2016.

Doğan Z., Dikmen B., (2018), Türkiye'deki Ulaştirma Sektörü Ve Ulaştirma Türlerinin Karşilaştirilmasi* Comparison Of Transportation Sector And Types Of Transportation In Turkey, Uluslararası Sosyal Araştırmalar Dergisi / The Journal of International Social Research Cilt: 11 Sayı: 56 Nisan 2018 Volume: 11 Issue: 56 April 2018.

Hepsağ, A. (2016). Testing convergence of tourism markets: evi-dence from seasonal unit roots test. Anatolia, 27(2), 177-188.

İmmers, L.H. ve Stada, J.E.:Basics of Transport Economics, Course H 111 Verkeerskunde Basis, Katholieke Universiteit of Leuven, Belgium, 2007.

İncekara B.,Dördüncü H.,Özer K.O, (2015). Turizm Ulaştirmasinin Denizyolu Ulaştirmaciliği Yönünden Gelişimi, Iktisat Politikası Araştırmaları Dergisi, Journal of Economic Policy Researches, Cilt/Volume:2, Sayı/Issue:1,Yıl/Year: 2015, 1-16

Kockelman, Kara, Chen, Donna, Larsen, Katie ve Nichols, Brice: "The Economıcs Of Transportatıon Systems:A Reference For Practitioners", Economic Considerations in Transportation System Development \& Operations, Texas, The Universty of Texas Austin, 2013.

Korosteleva Ekaterina. (2013). Turizm Lojistiğinde Ulaştirma Sisteminin Performans Analizi: Rusya Federasyonu'ndan Türkiye Cumhuriyeti'ne Gelen Turistler Üzerine Bir Çalişma, Dokuz Eylül Üniversitesi Sosyal Bilimler Enstitüsü Denizcilik İşletmeleri Yönetimi Anabilim Dali Lojistik Yönetimi Programi Yüksek Lisans Tezi,İzmir

Lakshmanan, T.R. ve Chatterjee, Lata R.: Economic Consequences Iransport If̧evrimiçi) http://www.uctc.net/access/26/Access\%2026\%20-\%2006 \%20-\%20Economic\%20Consequences \%20of\%20Transport\%20Improve ments.pdf, Erişim Tarihi: 20.07.2020

Özcan, B., Erdoğan, S. (2017). Are Turkey's tourism markets con-verging? Evidence from the two-step LM and three-step RALS-LM unit root tests. Current Issues in Tourism, 20(4), 425-442.

Özdemir K., (1995). TCDD (Türkiye Cumhuriyeti Devlet Demiryolları)'nın Tarihi Gelişimi Ve Demiryollarının Turizm Ulaştırması Açısından Önemi, İstanbul Üniversitesi / Sosyal Bilimler Enstitüsü Doktora Tezi, İstanbul.

Toda, H. Y.; Yamamoto, T., (1995), "Statistical Inference in Vector Autoregression with Possibly Integrated Processes", Journal of Econometrics, Volume 66, s. 225-250.

TÜROFED (Türkiye Otelciler Federasyonu) (2020, June 1). https://www.turofed.org.tr/_files/_pdf/RAPOR/turofed-turizm-raporu-2019.pdf.

(2019/1) Turizm Raporu, Retrieved from https://www.tursab.org.tr/istatistikler/turist-sayisi-ve-turizm-geliri. (18.07.2020).

www.bumko.gov.tr, Erişim Tarihi:10.03.2020. 